\title{
E-Governance in Bangladesh: Present Problems and Possible Suggestions for Future Development
}

\author{
Mohammad Jahangir Alam \\ Lecturer \\ Department of CSIT \\ Southern University Bangladesh \\ Chittagong, Bangladesh
}

\begin{abstract}
This is the era of Information Technology (IT). IT plays a vital role in daily life. To make transparent and effective the government works, to increase government efficiency, accountability and to improve the service delivery and participating the public in all aspects of government activities e-Governance is obligatory. Bangladesh government took the initiative to implement e-governance in 2001, but the implementation of e-Governance in Bangladesh is not up to the mark and the government is not getting the full benefits of e-Governance yet for many reasons. This research paper is focused on some current constraints of e-governance after surveying in the different sectors of Bangladesh and provided some possible suggestions to overcome those problems.
\end{abstract}

\section{Keywords}

Government-to-Citizen (G2C), Government-to-Business (G2B), Government-to-Government (G2G), Information Technology (IT), Information and communication technologies (ICT), Local Area Networks(LANs),Support to ICT Task Force (SICT).

\section{INTRODUCTION}

By the bless of e-governance, it is a real situation where people are getting all the government facilities round the clock that mean all interaction with the government can be done through one counter 24 hours a day, 7 days a week without physically waiting in lines at government brick-bound offices. Each and every citizen able to contact with the government through a website where all forms, news and other information will be available $24 / 7$.

So, the term e-Governance is the effective and efficient use of modern information and communication technologies (ICTs) such as Internet, LANs and Mobile Phones to improve the activities of public sector organizations with a view to establish good and transparent governance and to promote democracy for any country. The final objective of e-Governance is to create good governance [1].

The features of good governance can be identified as follows:

- Transparency

- Efficiency

- Effectiveness

- Accountability

- Justice

- Reliability e. Participatory Democracy
- Accessibility

- Equity [2].

Above mentioned features can be achieved through proper implementation of e-Governance using of modern information and communication technologies.

In Bangladesh, an ICT task force was formed in 2001 headed by Ex Prime Minister Begum Khaleda Zia for introducing eGovernance. It was unfortunately true that they have tried to implement e-Governance overnight without taking proper steps. For the lack of proper planning the previous government could not implement e-Governance properly.

Present government has taken a priority based project regarding e-Governance. The national ICT Task Force headed by the Honorable Prime Minister herself has given more importance on recognizing challenges to implement nation-wide eGovernance. For the reason government has started a pilot projects in various sectors of the government called the Support to ICT Task Force. It is being implemented under the Ministry of Planning. Also, the Government of Bangladesh is getting considerable foreign co-operation in terms of financial assistance and technical collaboration for realization of eGovernance at a national scale.

\section{E-GOVERNANCE IS COMPOSED OF THREE MAJOR ACTORS}

Mostly, the government, citizen and business concerns are the three main actors in the e-governance. Such as:

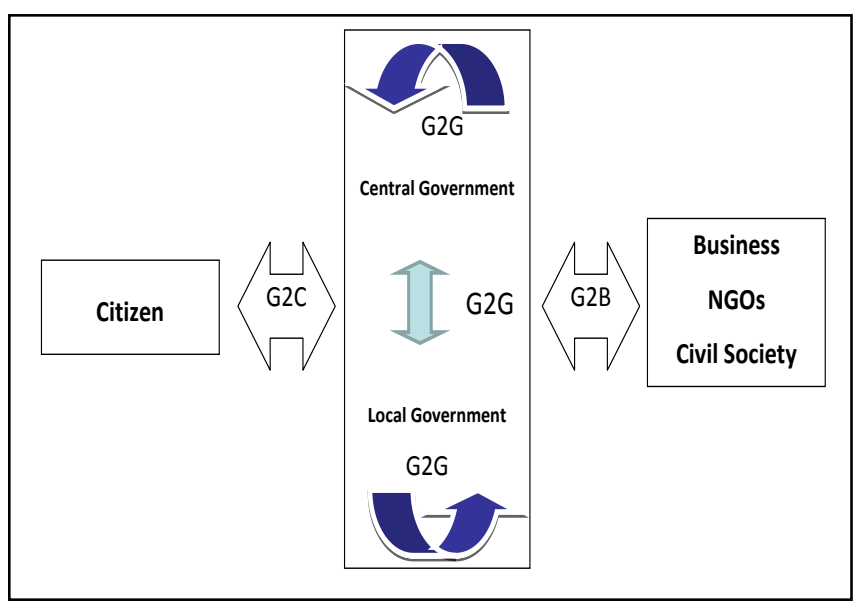

Figure-1: e-Governance model 


\subsection{G2C (Government to Citizen)}

This is the communication process of individual citizens with the government [3]. Payment of utility bills such as electric bill payment system using mobile phone is a common example of G2C. Another example of G2C is Bangladesh Road Transport Authority (BRTA) website (http://www.brta.gov.bd/index.php). Any citizen can see the driving license exam's result or download the driving licenses form using Bangladesh Road Transport Authority (BRTA) website. Government should develop more website for all sectors of Bangladesh to involve the public to make the successful e-Governance.

\subsection{G2B (Government-to-Business)}

This is the interaction between central government and the commercial business sector to get the businesses information. This interaction may involves many reasons such as to establish corporate, NGOs or others commercial business or downloading different types of form. Most common example of G2B is corporate tax paying system to the government using National Board of Revenue website (http://www.nbrbd.org/incometax.html) or applying for trade license from the government to run the business through internet using Office of the Registrar of Joint Stock Companies and Firms (http://www.roc.gov.bd:7781/) website.

\subsection{G2G (Government - to-Government)}

This is the non-commercial interaction between Government organizations, departments and authorities and other Government organizations, departments, and authorities. The example of G2G may be a request of allocation of budget by any department of the government. For example city corporation yearly budget depend on central government.

\section{SOME IMPORTANT E-GOVERNANCE SERVICE PROVIDING ORGANIZATIONS IN BANGLADESH}

- Bangladesh Planning commission [http://www.plancomm.gov.bd/about.asp]

- Department of Immigration \& Passport [http://www.dip.gov.bd]

- Support to Digital Bangladesh Project [http://www.a2i.pmo.gov.bd]

- National Web portal of Bangladesh [http://www.bangladesh.gov.bd]

- Bangladesh Association of International Recruiting Agencies (BAIRA) [http://www.hrexportbaira.org/index 2.htm]

- Bangladesh Bank [www.bangladesh-bank.org]

- Bangladesh Bureau of Educational Information and Statistics (BANBEIS) [http://www.banbeis.gov.bd/webnew]

- Bangladesh Civil Service (Administration) Academy [http://www.bcsadminacademy.gov.bd]

- Bangladesh Computer Council [http://www.bcc.net.bd]

- Bangladesh Export Processing Zones Authority (BEPZA) [http://www.epzbangladesh.org.bd]
- Bangladesh Fisheries Research Institute [http://www.fri.gov.bd]

- Bangladesh Forest Department [http://bforest.gov.bd/dev]

- Bangladesh Forest Research Institute [http://www.bfri.gov.bd]

- Bangladesh Hajj Information [http://www.hajj.gov.bd]

- Bangladesh Oil, Gas \& Mineral Corporation (Petrobangla) [http://www.petrobangla.org.bd]

- Bangladesh Overseas Employment and Services Limited (BOESL) [http://www.boesl.org.bd]

- Bangladesh Parjatan Corporation (Tourism Development Corporation) [http://www.parjatan.org]

- Bangladesh Public Service Commission [http://www.bpsc.gov.bd]

- Bangladesh Railway [http://www.railway.gov.bd]

- Bangladesh Road Transport Authority [http://www.brta.gov.bd]

- Bangladesh Road Transport Corporation [http://www.brtc.gov.bd]

- Bangladesh government all forms [http://www.forms.gov.bd]

\section{PROBLEMS OF IMPLEMENTING E-GOVERNANCE IN BANGLADESH}

\subsection{Internet connectivity}

Many of the government offices are out of Internet connection or using very slow Internet connection. Though, Bangladesh connected with high speed fiber optics connection but all of the government offices are not connected to the internet yet. So, most of government officials can not get the opportunity to use the internet and different types of government websites lack of internet connection and conputer. According to Internet world status report only 3.5 percent people use internet among the total population till 2011[4].

Table-1: Internet Usage and Population Statistics

\begin{tabular}{|c|c|c|c|c|c|}
\hline YEAR & Users & Population & $\begin{array}{l}\% \\
\mathrm{Pe} \\
\text { n. }\end{array}$ & $\begin{array}{l}\text { GDP } \\
\text { p.c.* }\end{array}$ & $\begin{array}{l}\text { Usag } \\
\text { e } \\
\text { Sour } \\
\text { ce }\end{array}$ \\
\hline 2000 & 100,000 & $134,824,000$ & 0.1 & N/A & $\underline{\text { ITU }}$ \\
\hline 2007 & 450,000 & $137,493,990$ & 0.3 & $\begin{array}{l}\text { US\$ } \\
466\end{array}$ & $\underline{\text { ITU }}$ \\
\hline 2009 & 556,000 & $156,050,883$ & 0.4 & $\begin{array}{l}\text { US\$ } \\
574\end{array}$ & $\underline{\text { ITU }}$ \\
\hline 2010 & 617,300 & $158,065,841$ & 0.4 & $\begin{array}{l}\text { US\$ } \\
624\end{array}$ & $\underline{\text { ITU }}$ \\
\hline 2011 & $\begin{array}{l}5,501,60 \\
9\end{array}$ & $158,570,535$ & 3.5 & $\begin{array}{l}\text { US\$ } \\
700\end{array}$ & $\underline{\text { ITU }}$ \\
\hline
\end{tabular}




\subsection{Internal network}

All Government offices of different ministries of Bangladesh are not within the same network. One ministry can not share their data with another ministry and government is not using properly the ICT in their offices. So the implementation e-governance is not very fruitful for the public.

\subsection{Security issues}

A modern organization requires security of all kinds of ICT assets where the government is no exceptional. Threats and attacks to the ICT assets may come in different forms from different sources. In the case of e-governance, the source of attacks can be internal or external to the government. With the sharp division of the government employees, the possibility of internal attacks should not be ruled out in Bangladesh. Employees who are working within e-governance projects may misuse the access privileges for financial or other gains. Threats may come from external sources like professional hackers, criminal organizations, terrorist organizations, intelligence and investigation agencies. Professional hackers, having excellent technical skills, can break into e-governance systems. The aim of such attackers is only a sadistic pleasure of disrupting egovernance services to the citizens. This attack may be occurred on financial sector in future when fully automated online transaction will be started in e-governance services.

\subsection{Central database problem}

Bangladesh government did not design any central database for citizen's access using through internet. Even there is no available information of any citizen in government offices to use any emergency situation. For this reason government officers have to face many difficulties to identify any person for any special reason.

\subsection{Problems at financial sectors}

It is not possible to transfer of funds through online from one bank to others banks using internet for the lack of national transaction gateway. There is no proper agreement with the international online payment gateway and the Central bank of Bangladesh yet. For this reason, it is not possible to transfer fund from any international bank to local bank from out side the Bangladesh.

\subsection{Automation of government agencies}

Government has developed many websites for the different government sectors but public can not getting the full benefits of e-Governance using different websites due to no-automation system of government websites. Such as, people can not fillup any online form of government website's to get full functional of e-governance services yet. People can not deposit annual income tax through National Board of Revenue (NBR) Website till now.

\subsection{Use of computer}

This is very common scenario is that Computers are seen of all government high level offices. Significant numbers of offices show it as status symbol. Because a large amount of the government senior officials don't like to use computer cause they have lack of interest to adjust with the new technology. For this reason most of the computers in the government offices shown only for status symbol. In a physical survey more than 50 government offices and interview from more than 100 government different levels officers. The report of the survey is as follows.

Table-2: Computer users at government offices

\begin{tabular}{|l|l|l|l|l|l|l|}
\hline $\begin{array}{l}\text { Types of } \\
\text { Employee }\end{array}$ & Age & $\begin{array}{l}\text { Excellent } \\
(\%)\end{array}$ & $\begin{array}{l}\text { Good } \\
(\%)\end{array}$ & $\begin{array}{l}\text { Avg. } \\
(\%)\end{array}$ & $\begin{array}{l}\text { Poor } \\
(\%)\end{array}$ & $\begin{array}{l}\text { Don’t } \\
\text { Use } \\
(\%)\end{array}$ \\
\hline $\begin{array}{l}\text { Senior } \\
\text { officers }\end{array}$ & $51-60$ & 2 & 5 & 15 & 43 & 35 \\
\hline $\begin{array}{l}\text { Mid } \\
\text { level } \\
\text { officers }\end{array}$ & $41-50$ & 10 & 18 & 43 & 24 & 5 \\
\hline $\begin{array}{l}\text { Junior } \\
\text { Officers }\end{array}$ & $30-40$ & 15 & 35 & 40 & 7 & 3 \\
\hline $\begin{array}{l}\text { Junior } \\
\text { Officers }\end{array}$ & $\begin{array}{l}\text { Below } \\
30\end{array}$ & 30 & 45 & 20 & 3 & 2 \\
\hline
\end{tabular}

\subsection{Financial problems}

Bangladesh is a developing country. Financial limitation is the main barrier for implementing any project. Government has to consider many things to implement any large project. Most of the times, government has to depend on foreign investors, developed countries or World Bank. Without support of others Bangladesh government can not run any large project with self fund.

\subsection{Public awareness about government portal}

The majority of the government officials and public are unaware about the e-Citizens Service application portal. Very few percent of the government officials and general people of the country are aware about the portal. Only few portions of the people are using the e-governance portal.

Table 3: Awareness about e-Citizens service application portal.

\begin{tabular}{|ll|r|r|r|r|}
\hline & & Frequency & Percent & Valid Percent & $\begin{array}{c}\text { Cumulative } \\
\text { Percent }\end{array}$ \\
\hline Valid & Yes & 20 & 20.0 & 20.6 & 20.6 \\
& A little bit & 26 & 26.0 & 26.8 & 47.4 \\
& No & 51 & 51.0 & 52.6 & 100.0 \\
& Total & 97 & 97.0 & 100.0 & \\
Missing & System & 3 & 3.0 & & \\
Total & & 100 & 100.0 & & \\
\hline
\end{tabular}

Table-3 reveals that majority of the respondents are unaware about the e-Citizens Service Application portal and only 20 percent respondents are aware. A significant portion of the respondents have heard about this initiative but never tried to this portal [5].

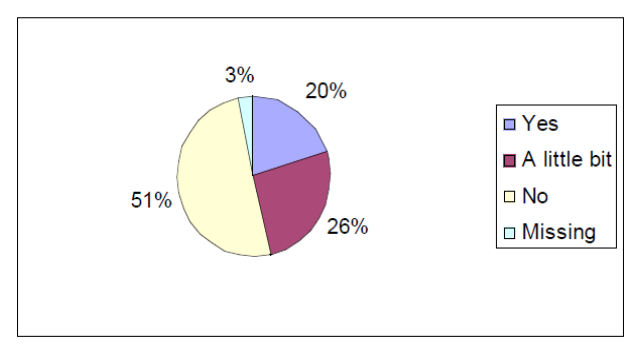

Figure2: Awareness about e-Citizens service application portal. 


\subsection{Lack of Training}

Trained people can play the vital role for implementing egovernance project. Unfortunately, majority portion of government officials do not have enough training on Computer yet. It is a big barrier for implementing e-governance.

\section{POSSIBLE SOLUTIONS FOR IMPLEMENTING E- GOVERNANCE IN BANGLADESH}

\subsection{Internet connection till village level}

To gain the ICT knowledge and for participating the egovernance activities internet connection from city to village level is very important. Without using internet no one can access the government web portal for their personal tasks. In the perspective of Bangladesh, this is not so easy for government to provide internet connection till village level within short time. So, government should encourage the private companies to provide internet connection to the public with cheap rate. So that villagers can access the internet easily.

\subsection{ICT infrastructure}

ICT infrastructure is an essential part to establish e-Governance in any country. Bangladesh government has to build ICT infrastructure step by step till village level to make the successful of e-Governance. Though, government has taken a Road Map or master plan for e-Governance using the limited resources. So government has to give more concentration to build ICT infrastructure within shortage possible time.

\subsection{Makes automation of government services and applications}

Government has to develop different types of applications in different websites so that any people can fill up and submit the different types of forms through internet without visiting government offices. If the people get the opportunity to execute their all kinds of governments officials tasks through internet it will bring force to implement the e-Governance and people will get the fruitful of e-Governance within shortest possible time.

\subsection{Automation of online financial transaction}

Bangladesh Bank should take necessary steps of online funds transfer from one bank to any other banks within and outside of Bangladesh to smoothly perform all kinds of banking transaction. Because, Bank to Bank online funds transfer process also play the vital rules in people daily life which is very important to implement the e-Government and involved the people in e-Governance.

\subsection{Proper training}

It is very important to provide training to the all government officers regularly. Without proper knowledge of IT of government officers' e-governance project will never see the real face of the project.

\subsection{Computer education mandatory for all officials}

Government should do the obligatory of computer training or computer knowledge to join any government profession. If government makes it as a role so that all young generation must take the computer training before applying any government job. As a result, government will get IT trained employee which is helpful for the e-governance.

\subsection{Database of citizen}

Government needs a national database to make the eGovernance project successful in every aspect. We know that Bangladesh election communication has a database of voter list where each voter has a unique identification no. So, government can use this information and database with adding some additional information of citizen as a national database.

\subsection{Motivate the public to use the government websites}

This is not a main aim of e-governance only involvement government officers in the e-governance project. Without public involvement it will not be a successful project. So, government has to take some steps to motivate the public to use different types of government web sites for their daily official tasks. Government can do it by sending SMS, arranging different types of seminar, symposium, showing short films to the public places and broadcasting some drama and advertisement in Television so that they know the advantages of e-governance.

\subsection{Financial solution}

This is not a big problem for government to arrange fund for establishing e-Governance project. Government can take financial support from many foreign organizations such as UNDP, UNESCO, ADB, World Bank, EU or other sources. Government can minimize the cost of e-Governance project using locally made software. After all if the government wants e-governance can be implemented economic way using self resources.

\subsection{Long term planning for governance applications Security Issues}

Security issue is the major concern in all of aspects of eGovernance. Different types of cyber attacks may come to different sectors of e-Governance. So, Government should takes strong modern long term planning to protect the e-governance all kind of websites, automation systems and software protect from any kind of cyber crime or attacks using modern and updated technology and policy.

\section{CONCLUSION}

There is a proverb that Knowledge is power but today it is acknowledged that information is power. So, proper information can be passed through e-governance within short time for all people. On successful completion of egovernance project on the allocation of the above mentioned discussion on this paper, people will get one stop service from the public offices. It will save time and money, be helpful to develop ICT based generation and to increase the economic growth.

\section{REFERENCES}

[1] Md. Anwarul Kabir, e-governance discourse: reality in bangladesh, published on february 13, 2007

[2] Dr. M. Lutfar Rahman, e-government and its security, http:// 
www.thedailystar.net/suppliments/2011/anniversary/part1/ pg13.htm

[3] Sasm Taifur, PROBLEMS OF E-GOVERNANCE IN BANGLADESH and possible steps towards solutions, http://goliath.ecnext.com / coms2 /gi_0199683885/introducing-e-government-in-bangladesh.html

[4] Internet

World

Stats, http://www.internetworldstats.com/asia/bd.htm

[5] Prof. I. Kushchu, Md Wahidul Habib , Chowdhury Golam Hossan, success and failure factors for e-government projects implem- entation in developing countries: a study on the perception of government officials of Bangladesh,2011
[6] Population and housing census 2011 Bangladesh at a glance, 2011

[7] Ziauddin Ahmed, Electricity Crisis of Bangladesh: Result of Organizational Inefficiency?, Energy and Environment Research Vol. 1, No. 1; December 2011

[8] K.A.M. Morshed, E-Governance: Bangladesh Perspective, http://unpan1.un.org/intradoc/groups/public/documents/AP CITY/UNPAN026253.pdf

[9] Country Reports on Local Government Systems: Bangladesh,http://www.unescap.org/huset/lgstudy/newcountrypaper/ Bangladesh/ Bangladesh.pdf. 